\title{
Pengaruh Status Gizi Terhadap Kecerdasan Balita Usia 4-5 Tahun Peserta PMT-P Diwilayah Puskesmas Bandaran Kabupaten Pamekasan
}

\section{Mei Lestari Ika Widyyati}

Sekolah Tinggi Ilmu Kesehatan Nazhatut Thullab Sampang meilestari118@gmail.com

\begin{tabular}{|c|c|}
\hline INFORMASI ARTIKEL & ABSTRAK \\
\hline & Nutrisi adalah kebutuhan utama untuk balita. Pada usia balita merupakan \\
\hline 019 & salah satu kelompok target khusus 1000 hari pertama kehidupan, selama \\
\hline Publikasi: 26-12-2019 & $\begin{array}{l}\text { periode ini ada pertumbuhan yang cepat dan perkembangan dan rentan } \\
\text { terhadap kekurangan gizi. }\end{array}$ \\
\hline & Tipe penelitian ini adalah observasional dengan pendekatan kohort \\
\hline \multirow{5}{*}{$\begin{array}{l}\text { Kata kunci: } \\
\text { status gizi, } \\
\text { tingkat kecerdasan, } \\
\text { program pemulihan } \\
\text { makanan tambahan } \\
\text { (PMT-P) }\end{array}$} & $\begin{array}{l}\text { retrospektif, Populasi pada penelitian ini adalah anak usia } 4-5 \text { tahun yang } \\
\text { mengikuti program PMT-P, pendekatan penelitian dengan cara pengamatan. }\end{array}$ \\
\hline & Teknik sampling yang digunakan dalam studi ini menggunakan teknik \\
\hline & npling acak yang sederhana dengan sampel besar dilakukan dengan metode \\
\hline & $\begin{array}{l}\text { sampling probabilitas dengan jumlah sampel sebanyak } 70 \text { anak. } \\
\text { Hasil perhitungan signifikansi (SIG) hasil dari } 0,186 \text { lebih besar dari } 0,05\end{array}$ \\
\hline & $\begin{array}{l}\text { sehingga keseimbangan tidak ada pengaruh antara status nutrisi ke } \\
\text { kecerdasan anak usia } 4-5 \text { tahun untuk peserta PMT-P. }\end{array}$ \\
\hline \multirow{8}{*}{$\begin{array}{l}\text { Key word: } \\
\text { nutritional status, } \\
\text { intelligence level, } \\
\text { additional food } \\
\text { recovery program } \\
\text { (PMT-P) }\end{array}$} & ABSTRACT \\
\hline & Nutrition is a major need for toddlers. At the age of toddlers is one of the \\
\hline & special target groups 1000 the first day of lif \\
\hline & of research is observational with a retrospective cohort approach, \\
\hline & The population in this research is a child aged $4-5$ years old who follows the \\
\hline & ogram, a research approach by observing sampling techniques in this \\
\hline & $\begin{array}{l}\text { chniques with large samples done by } \\
\text { of samples as much as } 70 \text { children. }\end{array}$ \\
\hline & $\begin{array}{l}\text { Result calculation of significance (SIG). } \\
\text { results of } 0.186 \text { greater than } 0.05 \text { so that balance no influence between } \\
\text { nutritional status to intelligence children aged } 4-5 \text { years for PMT-P participants }\end{array}$ \\
\hline
\end{tabular}

\section{PENDAHULUAN}

Nutrisi memainkan peran penting dalam perkembangan otak dari mulai saat konsepsi hingga usia 3 tahun (Cusick, 2016). Gizi merupakan kebutuhan yang utama bagi balita. Pada usia balita merupakan salah satu kelompok sasaran khusus 1000 hari awal kehidupan, pada periode tersebut terjadi pertumbuhan dan perkembangan yang sangat cepat serta beresiko mengalami kekurangan gizi (Kemenkes, 2012). Pada masa awal kehidupan anak, orangtua wajib memastikan bahwa asupan nutrisi yang diberikan cukup selama periode menyusui dini dan masa awal anak mengenal makanan (Ferrara, 2017), berdasarkan hasil penelitian intervensi stimulasi dan nutrisi yang diberikan dalam 2 tahun pertama kehidupan dan dilakukan secara konsisten di negaranegara berpenghasilan rendah dan menengah telah menunjukkan manfaat jangka pendek yang positif untuk perkembangan dan pertumbuhan awal anak (Yousafzai, 2016).

Menurut WHO (World Health Organization) 50 \% lebih bayi meninggal ataupun anak akibat kekurangan gizi dan gizi buruk, oleh karena itu masalah gizi perlu ditangani dengan cepat dan tepat (Kemenkes, 2011)

Hasil Riskesdas pada tahun 2013 menunjukkan angka kejadian kekurangan gizi pada banyak balita $(\mathrm{BB} / \mathrm{U}<-2 \mathrm{SD})$ terlihat gambaran yang tidak stabil dari $18,4 \%$ pada tahun 2007, berkurang $17,9 \%$ pada tahun 2010 kembali bertambah kemudian menjadi 19,6\% pada tahun 2013

Jumlah balita BGM dan gizi buruk di Puskesmas Bandaran Kabupaten Pamekasan, Madura, Jawa Timur terus 
bertambah. Berdasarkan data sekunder di Pusksesmas Bandaran Kabupaten Pamekasan, kasus gizi buruk pada awal Februari 2017 berjumlah empat orang, memasuki akhir Maret 2017 jumlahnya bertambah menjadi 34 orang

Menurut penelitian Primadianti (2010) tentang hubungan status gizi dengan tingkat kecerdasan intelektual (Intelegence Quotient-IQ) pada anak sekolah dasar di tinjau dari derajat sosial ekonomi kedua orang tua dan derajat pendidikan ibu menunjukkan bahwa status gizi berhubungan dengan IQ anak (anak dengan kondisi gizi lebih rendah memiliki skor IQ 13 poin lebih rendah sementara anak yang memiliki status gizi lebih bagus memiliki tingkatan IQ 10 poin lebih banyak)

\section{METODE PENELITIAN}

Pendekatan penelitian dengan cara observasional, melakukan pengamatan tanpa memberikan perlakuan terhadap populasi tetapi menganalisis pengaruh variabel yang sudah ada. Pengamatan dilakukan secara terencana antara lain melihat, mendengar, dan mencatat sejumlah kegiatan tertentu yang ada hubungan dengan penelitian yang sedang dilakukan (Notoatmodjo, S. (2015). Penelitian ini dilakukan dengan menggunakan rancangan Kohort Retrospektif yang dilakukan pada anak kelompok usia 4-5 tahun yang pernah mengikuti Program Makanan Tambahan Pemulihan (PMT-P)

Dalam penelitian ini tehnik pengumpulan data dikumpulkan langsung dari responden dengan menggunakan instrumen penelitian berupa hasil observasi dan tes pada seluruh responden yang memenuhi kriteria sampel.

Tehnik pengambilan sampel pada penelitian ini menggunakan tehnik simple random sampling dengan besar sampel dilakukan dengan metode pengambilan sampel probabilitas, metode ini memungkinkan setiap individu atau objek penelitian memiliki kesempatan dipilih sebagai sampel penelitian. Penentuan besar sampel penelitian ini menggunakan rumus Penentuan besar sampel penelitian menggunakan rumus Lemeshow untuk penelitian Kohort Retrospektif

variabel yang akan diukur adalah satus gizi kemudian mengukur kecerdasan intelektual

teknik pengambilan data, Pengukuran status gizi di lakukan di rumah kader masing-masing desa dengan bantuan petugas kesehatan sedangkan tes IQ menggunakan Stanford-Binet Intelegence Scale dilakukan dengan bantuan Psikolog anak di Poli Tumbuh Kembang Rumah Sakit Jiwa Menur Surabaya, waktu yang dibutuhkan untuk pengukuran test IQ 30 menit setiap anak.

Stanford-Binet Intelegence Scale merupakan merupakan salah satu metode pemeriksaan intelegensi anak untuk menilai tingkat kognitif, intelektual, dan neuropsikologis serta menilai kecerdasan umum (Dombrowski, 2015). Analisis data dilakukan sesuai dengan ketentuan penelitian kuantitatif yaitu diinterpretasikan dan di analisis dari awal hingga selesai penelitian. Model statistik yang digunakan adalah uji analisis regresi linear. etika pengambilan data dengan menjelaskan tujuan penelitian dan meminta tanda tangan lembar inform consent kepada orang tua responden, setelah itu peneliti mengukur status gizi, dan wawancara tentang pola makan anak pada ibu responden

\section{HASIL PENELITIAN}

Tabel 1.1 Karakteristik Umur Balita saat pertama kali ikut program PMT-P di Wilayah Kerja Puskesmas Bandaran Kabupaten Pamekasan

\begin{tabular}{ccc}
\hline Umur & Jumlah & $\%$ \\
\hline$<1$ tahun & 8 & 22,9 \\
\hline $1-2$ tahun & 12 & 34,3 \\
\hline$>2$ tahun & 15 & 42,9 \\
\hline Total & 35 & 100
\end{tabular}

Dari tabel 1.1 diatas dijelaskan bahwa berdasarkan paling banyak umur anak saat diberikan program PMt-P pertama kali adalah pada usia lebih dari 2 tahun sebanyak $15(42,9)$ balita.

Tabel 1.2 Karakteristik Umur Balita saat ini di Wilayah Kerja Puskesmas Bandaran Kabupaten Pamekasan

\begin{tabular}{ccc}
\hline Umur & Jumlah & $\%$ \\
\hline$\geq 3$ tahun 6 bulan -4 thn & 12 & 34,3 \\
\hline$>4$ tahun -5 tahun & 23 & 65,7 \\
\hline Total & 35 & 100 \\
\hline
\end{tabular}

Dari tabel 1.2 diatas dijelaskan bahwa berdasarkan umur anak saat dilakukan pengukuran status gizi dan IQ adalah sebanyak $23(65,7 \%)$ artinya bahwa hasil program ini dilihat ketika umur anak sudah mendekati usia lima tahun

Tabel 1.3 Karakteristik Status Gizi balita saat pertama ikut Program PMT-P Balita di 
Wilayah Kerja Puskesmas Bandaran Kabupaten Pamekasan

\begin{tabular}{lcc}
\hline \multicolumn{1}{c}{ Umur } & Jumlah & $\%$ \\
\hline Sangat Kurus & 7 & 20 \\
\hline Kurus & 28 & 80 \\
\hline Normal & 0 & 0 \\
\hline Gemuk & 0 & 0 \\
\hline Total & 35 & 100 \\
\hline
\end{tabular}

Tabel 1.3 diatas status Gizi balita saat pertama ikut Program PMT-P Balita sebanyak 7 (20) balita sangat kurus menandakan status gizi balita kurang BB normal sesuai anak seusianya

Tabel 1.4 Distribusi hasil uji Stanford-Binet Intelegence Scale Balita di Wilayah Kerja Puskesmas Bandaran Kabupaten Pamekasan

\begin{tabular}{llll}
\hline Nilai & Kategori & Jumlah & $\%$ \\
\hline$<70$ & $\begin{array}{l}\text { Intellectual } \\
\text { Deficient }\end{array}$ & 0 & 0 \\
\hline $70-79$ & Bordline & 0 & 0 \\
\hline $80-91$ & $\begin{array}{l}\text { Slow } \\
\text { Leaner }\end{array}$ & 18 & 51,4 \\
\hline $92-110$ & Rata-rata & 17 & 48,6 \\
\hline $111-119$ & $\begin{array}{l}\text { Rata-rata } \\
\text { atas }\end{array}$ & 0 & 0 \\
\hline $120-129$ & Superior & 0 & 0 \\
\hline$>129$ & $\begin{array}{l}\text { Sangat } \\
\text { superior }\end{array}$ & 0 & 0 \\
\hline Total & & 35 & 100 \\
\hline
\end{tabular}

Berdasarkan tabel 1.4 diatas dapat
dijelaskan bahwa kategori kecerdasan anak yang mendapatkan PMT-P dengan Status Gizi kurang lebih dari 18 51,4\% balita masuk pada kategori slow leaner.

Tabel 1.5 hasil uji statistic status gizi dan tingkat kecerdasan Balita di Wilayah Kerja Puskesmas Bandaran Kabupaten Pamekasan

\begin{tabular}{cccccc}
\hline Model & \multicolumn{2}{l}{$\begin{array}{l}\text { Unstandard } \\
\text { Coefficient }\end{array}$} & $\begin{array}{l}\text { Standarized } \\
\text { coefficient }\end{array}$ & t & sig. \\
& B & Std.Eror & Beta & t & \\
\hline 1 Constant & 3,072 & 0,213 & & 14,449 & 0 \\
\hline $\begin{array}{c}\text { IQ } \\
\text { Terpapar }\end{array}$ & $-1,83$ & 0,136 & $-0,229$ & $-1,349$ & 0,186 \\
\hline
\end{tabular}

Berdasarkan tabel diatas dijelaskan bahwa diketahui nilai signifikansi (sig.) sebesar 0,186 lebih besar dari 0,05

\section{PEMBAHASAN}

Berdasarkan umur saat ini sebagian besar responden kelompok mendapatkan PMT-P dan PMT-P mendekati usia 5 tahun. Umur anak saat mengikuti program pemulihan pada kelompok terpapar sebagian besar saat anak berumur $>2$ tahun. Status gizi balita saat mengikuti program pemulihan pada kelompok yang mendapatkan PMT-P sebagian besar dalam kategori kurus. Kondisi diatas sesuai dengan penelitian edem, et.al (2015) yang melakukan penelitian pada balita yang mengalami kondisi malnutrisi $80 \%$ berusia 1-2 tahun, hal tersebut disebabkan karena usia balita termasuk dalam kategori konsumsi aktif, serta merupakan usia efektif untuk perbaikan gizi pada anak. Anak dibawah lima tahun merupakan kelompok yang menunjukkan pertumbuhan berat badan yang sangat pesat, namun kelompok ini juga merupakan kelompok yang paling sering mengalami kekurangan gizi, karena masa-masa tersebut merupakan masa peralihan antara saat anak disapih dan mulai mengikuti pola makan orang dewasa. Menurut Fatimah 2013, menyebutkan bahwa berdasarkan hasil penelitian yang dilaksanakan menyatakan bahwa Tingginya angka kejadian gizi buruk balita di daerah terjadi akibat kurangnya asupan gizi penting meliputi karbohidrat, protein, vitamin serta lemak. Pada usia tersebut anak mengalami proses pertumbuhan dan perkembangan untuk mandiri, berperilaku menyesuaikan dengan lingkungan, terjadi peningkatan berbagai kemampuan, dan berbagai perkembangan lain yang membutuhkan fisik yang sehat, kesehatan yang baik ditunjang oleh keadaan gizi yang baik merupakan hal yang utama untuk tumbuh kembang yang optimal bagi anak (Santoso, 2011).

Berdasarkan karakteristik kecerdasan intelektual balita dengan menggunakan uji Stanford-Binet Intelegence Scale, pada kelompok balita yang mendapatkan PMT-P dengan kategori slow leaner sebesar $(51,4$ $\%)$, kategori rata-rata (48,6\%). Berdasarkan hasil perhitungan uji nilai signifikansi (sig.) hasilnya sebesar 0,186 lebih besar dari 0,05, tidak ada pengaruh antara status gizi terhadap kecerdasan anak usia 4-5 tahun bagi peserta PMT-P.

Berbeda dengan Penelitian sebelumnya yang menyatakan bahwa terdapat hubungan antara malnutrisi anak usia dini dan perkembangan kognitif dan behavioral berikutnya, yang disebabkan karena factor asupan mikro maupun makronutrien yang kurang (Ursula, 2016), perbedaan ini bisa dijelaskan karena status gizi yang jadi acuan penelitian ini Berat badan dibandingkan dengan Tinggi Badan.

Hasil penelitian diatas sesuai dengan penelitian yang pernah dilakukan oleh Amelia (2009), dengan menggunakan uji WISC (Wechsler Intelligence Scale for 
Children) menyatakan bahwa rata-rata nilai IQ anak yang pernah menderita gizi buruk lebih rendah 13,7 poin dibandingkan anak yang tidak pernah menderita gizi buruk yang secara statistik berbeda

\section{KESIMPULAN}

Tidak ada pengaruh antara status gizi terhadap kecerdasan anak usia 4-5 tahun bagi peserta PMT-P.

\section{DAFTAR PUSTAKA}

Amelia, Lies Karyadi., (1980). "Dampak Kekurangan Gizi Terhadap Kecerdasan Anak SD Pasca Pemulihan Gizi Buruk" (2).

Cusick, S. E., \& Georgieff, M. K. (2016). The Role of Nutrition in Brain Development: The Golden Opportunity of the "First 1000 Days." The Journal of Pediatrics, 175, 16-21.

Departemen Kesehatan Republik Indonesia (Depkes RI).(2012). Pedoman Kegiatan Gizi Dalam Penanggulangan Bencana. Jakarta: Kemenkes RI

Departemen Kesehatan Republik Indonesia. (2013). Riset Kesehatan Dasar Nasional. Jakarta: Badan Penelitian dan Pengembangan Kesehatan

Dinkes Pamekasan. (2015). Profil Kesehatan Kabupaten Pamekasan Tahun 2015: dinkes Pamekasan

Dombrowski, S. C., Canivez, G. L., Watkins, M. W., \& Alexander Beaujean, A. (2015). Exploratory bifactor analysis of the Wechsler Intelligence Scale for Children-Fifth Edition with the 16 primary and secondary subtests. Intelligence, 53, 194-201.

Edem M.A., Eric K. Sifah. Edmun T. N., (2015) factor affecting malnutrition in children and the uptake of intervention to prevent the condition Journal BMC Pediatric, 1(5) 189-195

Fatimah. (2013). Hubungan ketahanan pangan tingkat keluarga dan tingkat kecukupan zat gizi dengan status gizi batita di desa gondangwinangun tahun 2012. Jurnal Kesehatan Masyarakat Universitas Diponegoro, 2(2).

Ferrara, P., Corsello, G., Quattrocchi, E., Dell'Aquila, L., Ehrich, J., Giardino, I., \& Pettoello-Mantovani, M. (2017). Caring for Infants and Children Following Alternative Dietary Patterns. The Journal of Pediatrics, 187, 339-340.e1.
Kemenkes. (2011). Strandar Antropometri Penilaian Status Gizi Anak, Jakarta: Kemenkes RI

Kemenkes. (2012). Profil Kesehatan Indonesia Tahun, Jakarta.

Notoatmodjo, S. (2012). Metodologi Penelitian Kesehatan. Jakarta: Rineka Cipta

Santoso, Singgih, (2009) Statistik Non Parametrik Konsep dan Aplikasi

Tooley, U. A., Makhoul, Z., \& Fisher, P. A. (2016). Nutritional status of foster children in the U.S.: Implications for cognitive and behavioral development. Children and Youth Services Review, 70, 369-374.

Yousafzai, A. K., Obradović, J., Rasheed, M. A., Rizvi, A., Portilla, X. A., TiradoStrayer, N., Memon, U. (2016). Effects of responsive stimulation and nutrition interventions on children's development and growth at age 4 years in a disadvantaged population in Pakistan: a longitudinal follow-up of a cluster-randomised factorial effectiveness trial. The Lancet Global Health, 4(8), e548-e55 